\title{
Strategic Social Partnerships for Change: A Framework for Building Sustainable Growth in Developing Countries
}

\author{
Cathy A. Enz \\ Cornell University \\ Crist Inman \\ La Paz Group \\ Melenie J. Lankau \\ Wake Forest University
}

\begin{abstract}
Becoming world class means joining the world class. Success in the global economy derives not just from meeting high standards for competition in world contests but also from strong relationships-networks that link to global markets and networks that build collective local strength.
\end{abstract}

-R. M. Kanter, World Class, p. 325

\begin{abstract}
One of the hallmarks of an increasingly global world is the opportunity for wider access to consumers, capital, and information from around the world. To capture global customers, companies and countries must build relationships that enhance access to knowledge, information, capital, and other resources needed to grow and compete effectively. As the importance of international relationships among varied groups of private investors, providers of services, and governments increases, the ability of developing countries to compete often is determined by the quality of their relationships with strategic partners.
\end{abstract}

The strategies devised and implemented for economic development have important outcomes for the citizenry of emerging economies (Andrews, 1980). To become competitive (i.e., to increase wealth) in the global economy, developing countries must shed their natural inclination toward protectionism and embrace both foreign partners and rivals without losing their social and cultural identities. The private and public sectors in developing countries need to build relationships with companies and countries that can provide them with innovative new ideas and knowledge, operational skills to meet global customers' high standards, and easy access to capital from around the world. Determining which of many possible ways in which to build relationships is not an easy or straightforward issue. Clearly, selection of a type of partnership is a choice with long-term consequences for a developing country. The form of partnering can either enhance or hamper sustainable development. Thus, the choice of how to think about 
strategic partnerships is as important as the choice of the specific partners with which one does business.

New frameworks are needed to understand the variety of different relationships that can be established and sustained in strategic multinational partnerships with developing countries. In this chapter, we explore a framework that considers the relationship between the business operating orientation of the multinational corporation (MNC) and the economic development orientation of the developing country. From this framework, we present four different models for building strategic partnerships and illustrate the types of business relations that emerge under each. In the latter portion of this chapter, we illustrate the four models for development in the country of Costa Rica because Central American countries are in the midst of inventing their own systems for future development. The approach that they take will shape economic growth, national transformation, and the long-term use of human capital. The chapter also concentrates on tourism services because tourism historically has been a major force in advancing economic growth for developing countries. Developing countries in many parts of the world are aware that they need to be more active and innovative in building their economies, and the use of tourism services is the most cost-effective and easily available means for many to begin the process.

\section{The Evolution of Strategic Partnerships}

Forming and building business relationships often has been likened to marriage and family, with all of its unique complexities. The analogy of marriage and family is particularly useful because it evokes the importance of trust, loyalty, and respect. It further highlights the role of emotion, values, and shared responsibilities. In forming business partnerships, two substantially different orientations can be evoked. Depending on the orientation adopted by partners, the relationship will focus on control and maximizing individual interests (what we call a self-interest orientation) or collaboration and maximizing community interests (what we call a social contract) (Donaldson, 1982). Different forms of strategic partnership are suitable for different situations and environmental conditions.

Since the industrial revolution, the dominant design for partnerships around the world has been based on the economic theory and justifications of self-interest and wealth maximization. This view is deeply rooted in the foundation of American enterprise theory and has been a guiding light for the industrial world for the past 200 years (Friedman, 1962). Parties enter into contracts with the expressed purpose of economic benefit to the key players. These transactional contracts often are limited in duration and possess well-specified performance terms (Rousseau, 1995). In this orientation, expansion into developing countries is a means to the end of enhanced shareholder wealth through growth in which the shareholders are a select and limited few partners. The agreements with strategic partners are equity focused and legal. In a self-interest orientation to partnership, foreign investors have one driving 
responsibility, both morally and legally, and that is to maximize the value of shares to those who have invested capital in the corporation or who are engaged in contracts that enhance the wealth of shareholders (Reich, 1998). In short, the parties to the contracts make promises to each other, and their commitments are to ensure their own wealth. Repeated mutually beneficial exchanges that appeal to their common interests will, over time, engender trust and sustain their business contracts (Creed \& Miles, 1996; Kramer \& Tyler, 1996).

Differences in management styles, cultural mores, business practices, and even language barriers have repeatedly threatened or destroyed relationships based on traditional profit-maximizing assumptions. Shane (1994), for example, found that the perceived trustworthiness of the international partners influenced the type of governing mechanism that a firm put in place when beginning to globalize. Others have found that negotiation styles and management beliefs across different cultures have made strategic alliances and global strategies challenging (Adler, Brahm, \& Graham, 1992; De Forest, 1994).

Market forces and increased access to knowledge and capital have governments, local investors, and citizens in developing countries more sensitive to the potentially negative long-term economic, environmental, and cultural effects of their current partnerships with corporations. International tourism is considered vital to providing needed foreign exchange earnings and capital to the economies of developing countries. However, the anticipated gains in economic benefits in many instances were offset by the numerous sociocultural and environmental changes that altered and often harmed the people and resources of a country (Oppermann \& Chon, 1997). These self-interest-focused contracts, although beneficial to the business partners, violated the social contract, defined by Rousseau (1995) as collective beliefs regarding appropriate behavior in a society.

As developing countries seek new ways of creating their futures, the opportunity for radically different forms of relationships emerge. Global competition also has begun to force MNCs to contemplate dramatic changes in their relationships with customers, employees, investors, and other stakeholders. As organizations and developing countries evolve and adapt to changes in business, the nature and forms of their strategic partnering also may evolve.

\section{Sustainable Economic and Environmental Development}

Organizations influence societies in developing countries in numerous ways. A well-documented pattern of social consequences emerges when developing countries begin to "modernize." Deep changes take place in the social structure and value systems of countries. To generate much-needed foreign revenues, service sector businesses often are the most easily available entry points to reaching global customers and modernizing. Tourism, for example, is an industry that many developing countries select as their 
primary vehicle for economic development. In so doing, these countries open their cultures to the rest of the world. With this opening comes often unexpected, and sometimes undesired, consequences. Statistically, the vast majority of tourists come from countries in the Northern Hemisphere. Most developing nations embracing tourism as a form of economic development are in the Southern Hemisphere. Hence, differences in the value and perception of time between cultures in the two hemispheres are profound. Although theoretically fascinating, these differences are problematic when developing service standards among tourism service providers.

To satisfy the exacting demands of tourists from developed economies, service providers and training authorities engage in wide-reaching attempts to alter the fundamental ways in which their working populations think and behave. On the surface, increasing the speed of service sounds like a relatively simple task-merely a matter of incentives - but in practice it often requires deep remodeling of sociocultural values. Incentives themselves are not without wide-reaching ramifications. For example, the introduction of tipping in many countries is linked to a loss of the native hospitality that prevailed prior to the development of these tourism practices.

In addition to the influences on the less visible and less tangible facets of a society, tourism development has an obvious influence on the way in which countries appear. Architectural patterns adapt to global standards. Many developing tourism economies offer tourism investment incentives that lead to rapid proliferation of hotel and attraction infrastructure, replacing indigenous homes and communities with buildings and activities suited for foreigners. These standardized architectural forms might leave countries and regions visually indistinguishable from one another.

Although tourism seems to have a cheapening effect on many aspects of local values and arts, it need not lead to a loss of meaning for local people. The Amish of Pennsylvania are cited as an example of sustained quilting tradition in the face of modernity (Boynton, 1986). Numerous authors have examined the effects of tourism as a means of modernizing people's values, resulting in the degeneration of customs and traditions into a mere "tourist show." Greenwood (1989), in a study of the Alarde (a ritual of the people of northern Spain), argued that by commoditizing the ritual, it no longer was viewed as significant by the towns-people. By contrast, the effects of tourism in Bali have shown that tourism strengthened Balinese arts, crafts, and tradition by providing profits (Noronha, 1979). In this instance, the economic interactions between Balinese and tourists bound the two parties together, but the Balinese were actively involved in how their traditions would be used in the exchange (Harrison, 1992).

For many countries, foreign investments by large MNCs brought new problems and failed to solve the need for industrialization. In Costa Rica, for example, the country's post-1960 business climate was 
divided between small-scale local industry and export-oriented, large foreign-owned corporations. In other countries in Latin America such as Guatemala and Chile, large corporations actively promoted interventions against egalitarian democratic governments (Sheahan, 1987). As these examples show, partnerships with individuals, government, and businesses in developing countries influence the structure of social relationships within those countries (Hall, 1991). In particular, the United States has had a dramatic impact on the development of Central America. In recent years, many developing countries have become fearful that their natural resources and people have been exploited by outsiders, causing both environmental and cultural harm without the anticipated economic benefits.

There also has been increasing international public and governmental recognition of the urgency of environmental issues resulting from the rise of industrial development on a global scale. Concerns by the international public, mostly in developing countries, about overpopulation and environmental degradation are creating pressures on organizations to modify current practices toward growth and expansion and to incorporate a more environmentally oriented strategic objective called sustainable development (Shrivastava, 1995). Lewellan (1995) defined the concept of sustainable development as a complex concept that implies the integration of three systems: the biological, the economic, and the social. The goals of the biological system are genetic diversity, productivity, and the resilience to thrive under changing conditions. The economic system ideally strives toward increased production of goods and services, the satisfaction of basic needs, the reduction of poverty, and increased equity. Social system goals might include cultural diversity, social justice, popular participation in politics, and increased gender equity. (p. 207)

Sustainable development requires global corporations to alter the way in which they conduct business to establish new and fundamentally different relationships with more explicit societal obligations and shared commitments to address social and environmental problems. The expectation that global businesses preserve the long-term viability of the planet through protective, community-enhancing agreements with governments and local citizens might have the effect of shifting the terms of partnerships. Whereas the international public is concerned with preservation and protection of natural resources, local citizens worry about poverty, unemployment, education, and their economic futures. The melding of these concerns requires a different approach to long-term, sustainable economic and environmental development.

\section{Social Contracts and the New Partnership}

Social contracts are the mutual expectations, promises, and obligations that members of society hold for their relationships with businesses, governments, and each other (Kochan, 1997; Rousseau, 1995). A social contract orientation is deeply rooted in culture and argues for partnerships that move the focus of 
business interests from the individual employee and employer or business partner relationships to include others. The common social interests of a full range of parties including citizens, public agencies, complementary local businesses, and governments, if considered thoughtfully, could have profound positive consequences for the economic and environmental development of a newly industrialized region. The partnerships are win-win arrangements in which all actors have responsibility for the development of the total community. The social contract orientation seeks to produce a long-term benefit for the entire citizenry, regardless of whether citizens are directly employed by a particular MNC or a local business. When a community and its foreign businesses recognize that they have common interests and build cooperative relations, trust will become the byproduct. As the work of Powell (1996) suggests, trust is neither chosen nor embedded; rather, it is learned and reinforced and, hence, is a product of ongoing interaction and discussion.

A social contract perspective suggests that individuals and organizations have an ultimate responsibility for society (Donaldson, 1982; Mahoney, Huff, \& Huff, 1994). In this view, social consciousness fuels relationships linking the good for any party to the good for all in the community. Maximizing individual interests is an orientation in marked contrast to maximizing collective benefits.

A social contract approach is similar to the moral model offered by Etzioni (1988) in which it is argued that individuals choose both their means and ends and that these are based on their values and emotions. Etzioni noted, "People do not seek to maximize their pleasure but [rather] to balance the services of two major purposes - to advance their well-being and to act morally" (p. 83).Researchers provide support for the idea that moral beliefs, altruism, and the institutionalization of normative practices are significantly more powerful in predicting behavior than are self-interest motives (Latane \& Darley, 1970; Tolbert \& Zucker, 1983). Hence, a social contract versus self-interest approach to economic development highlights the importance of caring for and about the needs and interests among all players in a community to ensure trust and commitment and that all obtain benefits.

A social contract approach rests on fulfilling the responsibilities of being a part of the context (Etzioni, 1993). It has as its base moral criteria such as the elimination of poverty, direct care for the poor, creation of employment opportunities, and widespread education of the citizenry. At its foundation is the idea that the genuine good for any individual in society rests with the good of all (Bowie, 1991). Because no contract exists in a vacuum, implicit social contracts influence how all forms of contracting are interpreted. Development and the solution to serious economic problems are beyond the capability of individual businesses to manage alone. To attempt to do so is to potentially lose competitive advantage. However, an effort to establish social contracts and obligations more explicitly as an 
operating orientation for all strategic partnerships could result in more sustainable and profitable contributions to the communities in which MNCs do business.

As more global business relationships emerge, a social contract orientation redefines the boundaries of care. Perhaps because of the shift to global identity, it becomes a greater leverage point for competitive advantage when global companies commit to and fulfill obligations that ultimately benefit the local community and all of its stakeholders, even when they are not attached to or affiliated with the organization. At the present time, both self-interest and social contract orientations exist concurrently, although forces in the environment are pushing companies and countries toward a change in orientation.

\section{Anticipating Changes}

Much of the literature on change argues that periodically there is a need for discontinuous versus incremental change, resulting in the emergence of a new and fundamentally different era (Tushman \& O'Reilly, 1997). We currently are in the period of discontinuous change shown in Figure 7.1 where the forms of strategic partnership are shifting due to increased concerns that MNCs should assume a broader social responsibility in their economic transactions (Shrivastava, 1995).

\section{FIGURE 7.1. S-Curves for Strategic Partnerships}

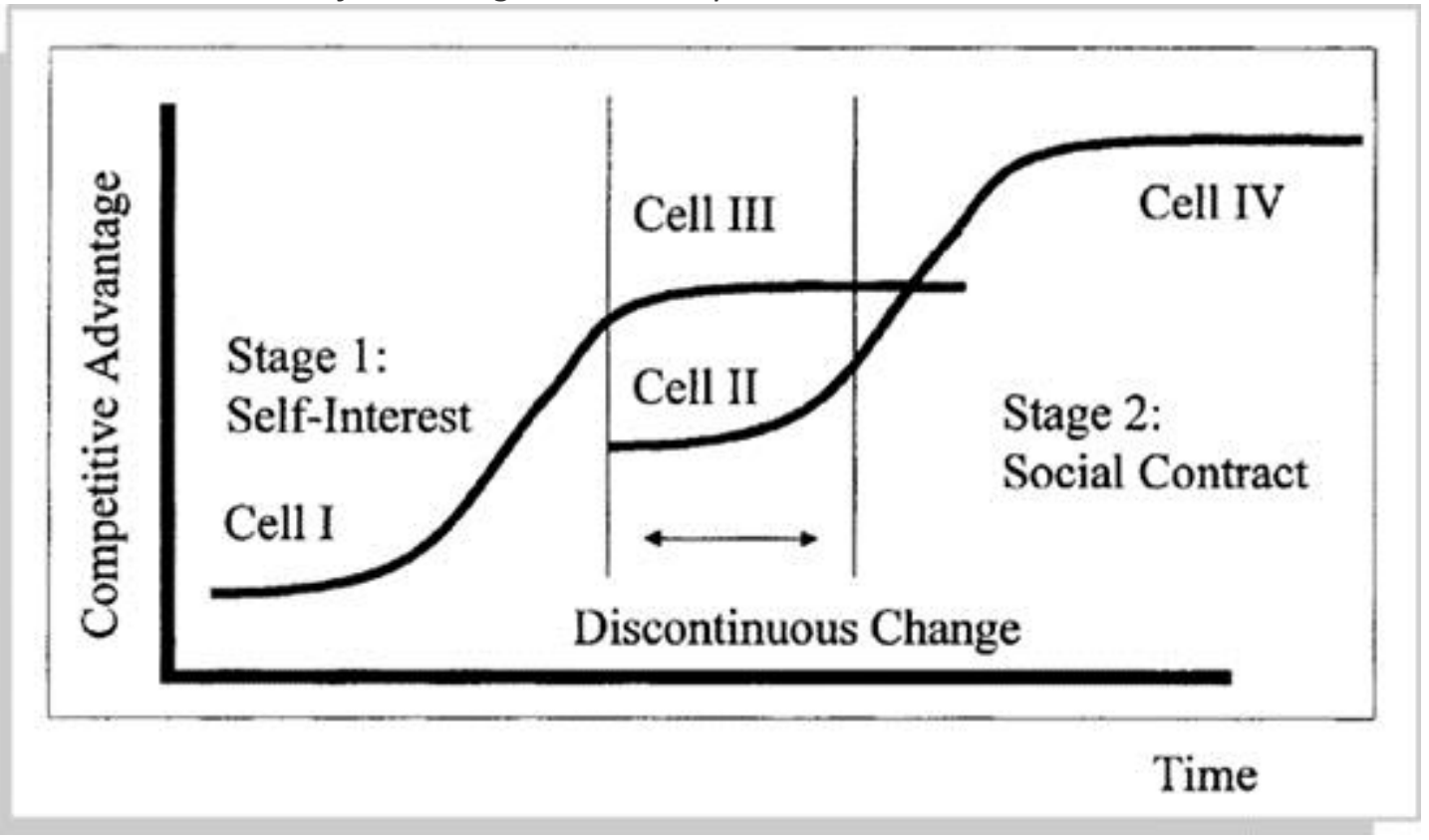

Using the familiar S-curve, Figure 7.1 illustrates the gradual evolution of a contract-focused self-interest orientation based on traditional economic theory. According to the S-curve, the cycle of benefit from 
this type of strategic partnership ultimately reaches a plateau where little incremental advantage is achieved from this approach. We may consider this end of the S-curve as the end of an era, as the selfinterest orientation no longer is the preferred form of international relationship building.

As Figure 7.1 suggests, during a period of discontinuity, the previous approach loses its advantage, necessitating a radically different approach. Social contracts are a new form of strategic partnership, based on cooperative community obligations, and can emerge as a powerful tool for socioeconomic development in an information-driven world.

We suggest that the most likely model for success in small developing countries is to consider developing social contracts and further that the traditional self-interest orientation might be losing its benefit for economic development. If one pursues a social contract or a self-interest approach, then these views will shape in different and noticeable ways the practical execution on economic development. The approach taken will alter human capital and its long-term development as well as the sustainability of natural resources.

Unexplored and assumed, the self-interest orientation will produce inescapable long-term outcomes. The operating success of businesses in developing countries will manifest itself in how management practice takes shape and how human resources are developed. To embrace one approach and its assumptions is to not embrace the other approach; this is why the shift requires radical change. Although different players might be working with different approaches, the net effect is that one will dominate because of governmental policy. Competitive, legal, economic, and cultural outcomes of each approach also will shape the viability of moving from one model to another.

Developing countries are at different levels of self-sustaining growth and economic development, making a radical shift to a social contract framework more or less likely in the short term. Some countries (e.g., Costa Rica) have been politically stable for decades and have high literacy rates, whereas other countries (e.g., Nicaragua) have long functioned under unstable military dictatorships in which the wealthy citizens have lived in exile in other countries. It is expected that nations will have varying degrees of growth and investment from inside versus outside the country and, as a result, will be constrained in the forms of partnership that they can design and use most effectively. This would suggest that although we predict an evolution to more social contract relationships, the possibility of other intermediary forms of relationships do exist and will continue to exist for countries driven by outside versus inside sources of capital, knowledge, and skills. In addition, some industries, such as technology and tourism, might move more quickly to social partnership than will agricultural and manufacturing-based industries. Given the business operating orientation of MNCs (self-interest vs. 
social contract) and the development orientation of developing countries (inside pull vs. outside push), we would expect different models of partnership. To explore this more fully, we pose the question:

What models or options for sustainable competitive development exist in emerging markets? In the next section, we provide four different models of partnership.

\section{Models for Building Cross-Cultural Strategic Partnerships}

Four different models for strategic partnership emerge from examining the interface between business operating orientation and the economic development orientation of a developing nation. Figure

7.2 shows the different types of strategic partnerships that can exist between companies and countries. We have labeled the four cells of our matrix according to the types of relationships that exist, as follows: Contractual Exchange (Cell I), Limited Social Covenant (Cell II), Joint Partnership (Cell III), and Integrated Social Covenant (Cell IV). Each cell in the matrix is discussed in turn.

FIGURE 7.2. Strategic Partnerships Between Foreign Companies and Developing Countries

\begin{tabular}{|c|c|c|c|}
\hline \multirow[b]{3}{*}{ } & & Business Opera & ting Orientation \\
\hline & & Self-Interest & Social Contract \\
\hline & $\begin{array}{l}\text { Outside } \\
\text { Push }\end{array}$ & $\begin{array}{l}\text { CONTRACTUAL EXCHANGE } \\
\text { Cell I } \\
\text { Little infrastructure in country } \\
\text { Few players in country } \\
\text { Country is dependent } \\
\text { Company has power } \\
\text { Country is short term } \\
\text { Company is short term } \\
\text { JOINT PARTNERSHIP } \\
\text { Cell III } \\
\text { More infrastructure in country } \\
\text { More players (due to develop- } \\
\text { ment of middle class) } \\
\text { New agreements/local owners } \\
\text { more flexible } \\
\text { Country is long term/short term } \\
\text { Country has power/can be } \\
\text { more selective in choosing } \\
\text { partners } \\
\text { Cooperation in meeting } \\
\text { respective goals }\end{array}$ & $\begin{array}{l}\text { LIMITED SOCIAL COVENANT } \\
\text { Cell II } \\
\text { Caretaker approach by company } \\
\text { Paternalistic/provide direct help } \\
\text { Less infrastructure } \\
\text { Fragmented relationships } \\
\text { Company is short term/present } \\
\text { Company is long term/future } \\
\text { INTEGRATED SOCIAL. COVENANT } \\
\text { Cell IV } \\
\text { Most infrastructure in country } \\
\text { Company takes local and global } \\
\text { perspective } \\
\text { Self-help model } \\
\text { Company and country both are } \\
\text { future oriented and long term } \\
\text { Holistic } \\
\text { Coordination of goals }\end{array}$ \\
\hline
\end{tabular}




\section{Contractual Exchange: Cell I}

MNCs that operate from a self-interest and outsider push orientation enter into traditional contracts that are short term and based on strategic initiatives to expand the corporate market, reduce costs, and maximize shareholder value. The developing country is characterized by an economic system that is largely dependent on foreign investment for growth and development of infrastructure. Because the means to economic growth for the country are focused outward and originate from external sources, a clear power differential exists, and the terms, forms, and benefits of the relationship are dictated by the MNCs.

The political and social systems in a country under a Cell I model are influenced and managed by an elite class of business and governmental players whose motivation also is driven by self-interest. The interactions of the few powerful MNCs and the country create a context in which partnerships are based

on contractual exchanges. This exchange is asymmetric because many developing countries cannot bring knowledge, skills, capital, or technology to the bargaining table but can offer governmental tax incentives, land, and inexpensive labor in exchange for developmental expertise, capital, and jobs. The gains for the country, however, are experienced or received not by the whole society but rather by the few business players who have the capacity in terms of land ownership, wealth, and influence to enter into these exchange relationships. In countries such as Costa Rica where there are many small land holders, the exchange might be less asymmetric, and the potential for personal gains for the citizenry might be greater.

This type of partnership is similar conceptually to the ideas of Williamson's (1975) transaction cost analysis and is applicable to both developed and developing countries. This form of partnering fosters an economic quid pro quo orientation in which there is little consideration of collective long-term benefits for the host community. Foreign investors are searching for short-term returns and are hesitant to build the infrastructure required to develop for the long term. Quick and standardized development projects are advocated to achieve synergies and rapid returns on investment. To secure capital and enhance the ease of working with foreigners, local investors and governments must demonstrate affiliation with the investing MNCs, altering their own social identities. To meet the economic ends they seek, local owners and country leaders support the values and strategies of the organizations despite the short-term orientation, lack of attention to the preservation of the country's natural resources, and minimal investment in skill development for the country's people.

Figure 7.3 summarizes each of the models on a variety of features-time orientation, cultural identification, learning relationship, management focus, and human resource strategy. This list of features is meant to be illustrative and incorporates the perspectives of both developing countries and 
global organizations. The categories examined in the figure are not exhaustive but are important and frequently cited factors. In addition, this figure does not attempt to differentiate among various forms of multinational structure and operation, although those differences in organizational form would likely influence the nature of the social partnerships.

FIGURE 7.3. Features of Different Strategic Social Partnerships

\begin{tabular}{|c|c|c|c|c|}
\hline Feature & Model I & Model II & Model III & Model IV \\
\hline \multicolumn{5}{|l|}{ Time orientation } \\
\hline Developing country & Short term & Short term & Building long term & Long term/short term \\
\hline Global organization & Short term & Building long term & Short term & Long term/short term \\
\hline \multicolumn{5}{|l|}{ Cultural identification } \\
\hline Developing country & Foreign host & Foreign host & Local & Local/global \\
\hline Global organization & Home country & Home country & Home country & Local/global \\
\hline Learning relationship & $\begin{array}{l}\text { Acquire } \\
\text { (transformation) }\end{array}$ & Correct & Adapt (internal) & Innovate \\
\hline \multirow[t]{2}{*}{ Management focus } & $\begin{array}{l}\text { Expatriates/ } \\
\text { standardized }\end{array}$ & Expatriates & Unique & $\begin{array}{l}\text { Both unique and } \\
\text { adaptive }\end{array}$ \\
\hline & $\begin{array}{l}\text { Fix disabilities/work } \\
\text { With limits }\end{array}$ & Unique (prescribed) & Evolving & \\
\hline \multirow{4}{*}{$\begin{array}{l}\text { Human resource strat- } \\
\text { egy }\end{array}$} & Low investment & High investment & Low investment & High investment \\
\hline & High control & High control & Low control & Low control \\
\hline & Minimize training & Not managers & $\begin{array}{l}\text { Highest worker } \\
\text { alienation }\end{array}$ & Mentoring \\
\hline & Survival focus & Worker compliance & & Teaching/listening \\
\hline
\end{tabular}

As the Figure 7.3 suggests, in a Cell I model of relationships, the short-term home country focus of organizations might be evident in the extensive use of expatriate managers and a minimal investment in the training and development of local citizens. Economic efficiencies ultimately reinforce societal inequalities, and learning is acquired from outside and imposed on the people within the country. The developing country identifies with the global firms and seeks to acquire the needed expertise to advance its own economic wealth.

\section{Limited Social Covenant: Cell II}

In Cell 2, the conditions and characteristics of the developing country are the same as in Cell I, but the operating orientation of the MNCs is vastly different. Owners and managers of these organizations are aware of the implications of the host community's dependence on their organizations and are more sensitized to the impact that productive corporations can have on local communities. These organizations operate with the assumption that strategies to optimize short-term gains undermine longer term benefits for the community and, most important, for the organizations as well. These 
companies hope to create long-term sustainable development for themselves through the process of contributing to the whole community. There is mutual consideration of what is best for the corporations and what is best for the national economy, culture, and people of the developing country.

Developing countries rely on global organizations for capital, technology, skills training, and development of infrastructure. However, these MNCs must manage the fragmented self-interest efforts of local business owners, investors, and government officials, and this may constrain the type of relationships that can emerge between multinational organizations and developing countries. Due to the imbalance of resources, MNCs with a sense of social responsibility are more likely to enter a developing country with a caretaking paternalistic orientation. The inability or unwillingness of the country's influential leaders and key organizations (business and political) to contribute to the social partnership, or the inability of the MNCs to create and sustain the network of relationships necessary for an integrated social partnership, creates a limited and potentially fragile social covenant.

Under these circumstances, the corporations provide direct help to the developing country. This limited social covenant will reinforce the country's outward dependence on externally driven growth. Much of the MNCs' efforts to contribute to the knowledge, skills, technology, and economic conditions of the community will not be sustainable in the long term and only serves the needs of the corporation and the few who are willing to take advantage of this paternalism in the short term.

As noted in Figure 7.3, these limited social covenants have promise for building the future.

Organizations that bring new learning opportunities and technology to correct existing inadequacies ultimately help to reduce the need for external capital and to improve employment opportunities. Companies that believe in the obligation to the local community still might identify with their home countries but also invest in building the skills and education of the local population. Because these companies are few in number, the effective reach of their efforts is heavily limited. In addition, managerial philosophies and human resource practices are likely to be prescribed by the global organization rather than created and established with the consideration of the local citizens' values and needs.

\section{Joint Partnership: Cell III}

In Cell III, the means for economic growth shifts to expanding the use of internal resources rather than relying on external sources of investment. Over time, the developing country experiences economic gains from Cell I and Cell II types of relationships, resulting in the development of a better level of infrastructure and an increased number of in-country or in-region investors interested in entering into partnerships. Access to information and capital makes these firms less dependent on large outsiders. 
These investors become more sophisticated in their relationships with foreign companies, producing more balanced and mutually favorable contracts. Hence, the cross-cultural strategic partnership can be characterized as a joint partnership. Increased competition provides these in-country investors with more potential partners and better terms. Deal structures are easier to put in place, and the easy access to capital markets provides countries with more bargaining power. Regional capital becomes more available, and a larger variety of contracts with an expanding number of businesses are evident. In short, the enclave-style (isolated pockets of development such as banana export) are replaced by more equally distributed locally led business development.

Companies become more willing and driven to venture outside of their traditional markets to do business in unfamiliar locations. The country relies less on a few large companies and becomes involved in more mutually beneficial contracts in which it takes on larger equity participation and lessens its dependence on First World standards and operating approaches. Within-country organizations and investors can be more selective in choosing their partners and the terms of those partnerships. MNCs, however, still are operating at a first-stage self-interest approach to partnership. Cooperation in the joint partnerships will be limited by the extent to which the MNCs are able to achieve their goals, which are essentially focused on the organizations' capital investors and stockholders and not on the host community.

Although this type of strategic partnership is more balanced in terms of equity and contribution on the part of businesses within the developing country, the commitment required to build and maintain a network of interorganizational linkages over the long term will not be provided by the MNCs. This creates a difficult challenge for the developing country-creating these networks and supporting them primarily through internal systems and resources. This challenge requires a level of infrastructure, economy, political stability, integration, and coordination of systems that takes time, money, and leadership that the developing country might be lacking.

A Cell III model is a transition model in uneasy harmony because it can slip into a locally protected domestic market or move back to a Cell I multinational-dominated system. As shown in Figure 7.3, local businesses are adapting and learning new business skills, and governmental policy can potentially restrict or limit the success of small players through regulation. Human resource strategies also are evolving, and the framework of enlightened self-interest might yield even more oppressive and exploitative practices than would be the case under foreign-led development because urban and racial bias evident in several countries in Latin America would influence the use of human resources (Sheahan, 1987). 


\section{Integrated Social Covenant: Cell IV}

A Cell IV, social covenant model of strategic partnerships exists when foreign companies and host countries work together for the local social good and long-term sustainable development of a region, city, country, or group of countries. Under these partnerships, the foreign companies and host country share a commitment to local prosperity and build long-term, integrated sets of business relationships. The ultimate goal is for strategic partnerships to aid the common interests. This approach is not selfless for the companies but rather an essential way in which to ensure long-term strategic competitive advantage and short-term business success.

The Cell IV model of relationships requires redefining the boundaries of care such that organizations must be partners in the local context to transact business. Global businesses are required to identify with the host country and consider themselves as local citizens. The social covenant approach realizes that the actions of one firm or group of firms have implications for the whole and that the terms of the relationship must be driven by a cooperative, collective, community, and inclusive operating orientation. Conducting business in isolation with a few privileged owners and investors within a country is an unacceptable practice in this model of relationships. In addition, the common interests are the focus of all businesses, not just a few (as we saw in the Cell II model). The internal organizational practices and strategic actions are considered to have implications for many actors including governments, employees, investors, managers, and communities. Hence, consideration of the effects of strategic and operational practices of each business on the whole is a necessary part of doing business for all. The objective is to work in collaborative efforts to benefit the entire society and its citizenry, not just customers, investors, managers, and employees.

A social covenant view is one that blends economic investment of individual businesses with social consciousness. The companies' and country's goals are oriented toward the future and are not exclusive but rather inclusive of the parties' contracts and relationships with their respective environments. There is an understanding of the whole, and the partnership is characterized by coordination rather than cooperation. Coordination differs from cooperation in that it involves a process of concerted decision making or action in which the parties participate in planned and integrated change with one another rather than pursue separate goals with a general orientation toward some common issue or outcome (Hall, 1991). A Cell IV approach to strategic social partnerships represents the best opportunity for a developing country and an MNC to work collaboratively to transform both of their abilities to compete in a global world.

Managers cannot rely on the ways of the past when partnerships move into an integrated social covenant. Practices and approaches must be created or invented with the local circumstances and the 
limits and potential of the citizens factored in. The view of low-skilled employees as deficient must be replaced with a mind-set that respects the skill levels that currently exist. It is appropriate for managers to devise a gradual process of development while simultaneously appreciating the current talents and skills of workers. As shown in Figure 7.3, the investment in human capital is very high, and the roles of mentor and teacher are dominant. Efforts to harmonize the more discriminating demands of global customers with the capabilities and education of the population require a development plan that brings together universities and colleges with businesses and governments in cooperative supportive relationships.

\section{The Model in Action}

We now turn to an examination of Costa Rica, which has for the past 20 years established itself as a global ecotourism destination. By examining this small Central American country, we can see in action the dynamics of working from and with several different models of strategic partnership. Costa Rica is interesting precisely because it is not a typical case among developing nations and because it provides a working model for what might be a more attractive development path. Although several countries in the Pacific Rim region have been held up as models, rapidly transforming themselves from developing, to newly industrialized, to "tiger" economies, these examples have not been applicable in many developing nations that have explicit democratic and egalitarian social mandates.

Costa Rican social and political traditions would not allow economic development that either stifled or disregarded the institutions of democracy at the national political level, or the institutions of social and economic equity at the company level, for the sake of economic development. Although there is much debate among social scientists about the nature of the relationship between democracy and economic development, the fact is that many developing nations have embraced democratic institutions as an ideal, so the challenge is to find models of economic development appropriate to the context of this ideal. There are numerous countries around the world that provide discrete examples of the various types and phases of partnerships we have proposed here. We have chosen Costa Rica because it already has achieved significant shifts in its economic development, is further along the S-curve of change, and may speak to the larger development of Mexico, Central America, and Latin America.

Tourism and complementary industries are chosen because these are the types of businesses that have migrated to the top of the economic development pyramid in Costa Rica. The choice of industries examined was less important than the choice of the nation that provided examples of various forms of social partnership. We do not expect that the type of industry is determinant of or determined by the phase or cell of development. Rather, as an artifact of history, the banana companies happened to be the first foreign partners (Cell I), followed by maquiladoras (Cell II), whereas now both tourism and 
technology-based manufacturing are key industries in later phases (Cell III and Cell IV) of development in Costa Rica. Because the economic activities discussed in the next section are so different in each cell, we believe that the focus on service industries in our model is generalizable to other industries and engines of economic growth.

\section{Social Partnership Options in Costa Rica}

\section{Contractual Exchanges in Costa Rica (Cell I)}

The history of Central American economic development is dominated by Cell I-type foreign investment. Beginning during the 1850s, foreign companies made deals with local governments and businesspersons, particularly on the Caribbean side of the isthmus, to acquire enormous tracts of land at very low prices for the cultivation of banana plantations. There were only a few companies, predominantly from the United States, but their vast landholdings and political influence grew strong enough that the countries in which they operated became known as "banana republics." ${ }^{1}$ This name grew out of a combination of factors. The companies became affiliated with and benefactors of local political parties, and they used these affiliations to ensure that strategic national decisions always were made with the banana companies' interests foremost in mind (Sheahan, 1987).

When decisions made at the national level were in conflict with the interests of the banana companies, various mechanisms were used to reverse them. Simplest was the use of both economic and social threats; the companies would shut down their operations, and their workers would be laid off, so not only would the countries lose the foreign revenues (modest as they were after the companies extracted their rents), but they would have to deal with pending social upheaval. More complex, but invoked numerous times, was the threat of military intervention from the U.S. military. Most countries in Central America were occupied at one time or another by the U.S. Marine Corps, instilling the obedience that came to be associated with banana republics.

This situation has changed considerably during recent years such that the banana companies can be said to have much more limited control over the governments of host countries. Yet, the instability and institutional weakness that their historical political actions created were inextricably linked to the attractiveness of Marxism as a liberating philosophy and, in turn, to the social, economic, and military chaos that unfolded during the second half of the 20th century in each of the countries except Costa Rica.

At its worst, Cell I development can lead to disaster on multiple fronts. Now that peace and relative stability have returned to the region for the first time in many decades, the multifaceted disasters of the 
banana republics have given way to more focused problems. In particular, although the banana companies still are rent seekers, their economic privilege is not questioned as much as is their environmentally destructive growing practices. These include the use of pesticides and fertilizers that are banned in the United States because of toxicity levels. Many of these pesticides and fertilizers are sold to Central American farmers by companies based in the United States that are prohibited from selling them in the United States but are allowed to produce them at home and sell them in foreign countries. The paradox is that they are used in the cultivation of produce that is then exported for consumption in the United States and Europe.

These practices also include the use of large plastic bags to cover every bunch of maturing fruit during the growing season. At harvest time, these millions of bags (a distinctive electric blue color) are removed from the fruit trees and discarded unsystematically. Some of these bags make their way to landfills, others are burned during the dry season, and the rest float around the countryside, making the Caribbean coast of the isthmus look as though the local population does not have enough pride to keep itself tidy. Because that same region is fertile for tourism development, the environmentally unsound practices of the banana plantations work at direct odds with the most significant economic alternative the locals have, which is to work in tourism-related jobs. There have been recent efforts to change some of these practices, and these are discussed in the Cell III subsection later.

The banana republic legacy has not completely been wiped away during the recent return to peace and stability. Not only are the banana companies alive and well (in terms of their own economic interests), but they have been joined by a group of new industries that function almost identically. One category of such industries represents the cutting edge of the Cell I form of foreign direct investment in developing economies - the maquiladora (or maquila for short). Maquilas are local production subsidiaries of foreign companies. They set up shop in Central American countries primarily because they are given tax incentives from the host countries and often from their home countries as well (especially those based in the United States).

With tax-free status in the host country and tax benefits back home, the inexpensive labor of the host country typically is an added benefit. Because this inexpensive labor typically is unskilled, the types of jobs that are sent with these maquilas are relatively low value-added jobs-parts assembly, sewing, and the like. On top of these benefits to the foreign companies, lax labor laws often permit the type of sweatshop conditions and child labor abuses that these companies could not get away with at home. Maquilas have been faulted not only for these rent-seeking activities but also for not leaving much value in the host country. Apart from the meager wages they pay, maquilas leave very little behind, repatriating revenues and profits to their home countries. Often, their production facilities are built for 
them as an incentive to bring their productive capital to the host country, but this productive capital is easily moved when more attractive offers appear elsewhere.

Another variation of the Cell I form of investment is found in the tourism sector in the form of large resort development companies that are given lucrative incentives to build in a host country. One difference between this sector and the maquilas is that a resort, once built, cannot be repatriated (except for managers, furniture, and equipment). But although foreign resort companies are putting up more capital that cannot be repatriated (thus, higher risk), this is balanced by several factors. The companies, like maquilas, are given tax incentives and often attractive financing conditions as well. More important, they occasionally are given environmental privileges not granted to others.

In coastal areas of Costa Rica, for example, there is a famous case of a megaresort project that was courted by the government and allowed to build its enormous infrastructure at the water's edge, even though the country's strict environmental laws clearly prohibited this. Only after strong public outcry was the project shut down. In another case, a world-renowned foreign resort company was allowed to replace hundreds of acres of ecologically critical mangrove forests with landfill and non-native palm trees that were believed to be more attractive to tourists.

Besides such questionable environmental practices, several of the large resort projects in Central America operate like maquilas in the sense that they pay low wages, provide little training, and repatriate the lion's share of their dollar-based revenues back to their home countries (in this case, Spain is the home country more often than the United States). Strategically, these firms are selling a mass tourism product that give customers a standardized and consistent worldwide product rather than a uniquely Costa Rican experience. Alternatives to these Cell I practices are evident in the Cell II orientation.

\section{Limited Social Covenants in Costa Rica (Cell II)}

In more recent history, large MNCs from around the world have been investing heavily in Central America, hoping that as peace and stability matured, market opportunities would follow.

Pharmaceutical, electronics, consumer and industrial goods, and other types of companies from North America, Europe, and Asia have made capital investments in Central America even without the tax incentives enjoyed by maquilas (which are created only for the purpose of exportation of their production). Besides these large MNCs, other investors from abroad come to the region and make significant investments in local businesses, bringing with them capital, technology, and managerial expertise. 
These investments assume that in the long run, the companies will enjoy a first-movers' advantage with excess returns because they have entered the economies of the region on the ground floor, prior to the competition. In the short run, the outlays for training and expatriate managers are excessive compared to the cost of operating in their home countries. But if the host economies develop, then the return on these investments eventually could become extremely profitable.

One company that represents a Cell II form of development is Intel, with its recent investment in Costa Rica. Worth a reported $\$ 200$ million, the facility that Intel began operating in San Jose in 1998 had roughly doubled the value of exports of the entire country by the end of its first year of operation. What is more, all of the expatriate managers who were brought from the United States to oversee construction and initial management of the facility were expected to replace themselves with Costa Ricans within the first year or so of operation. Although Intel does not have any Costa Rican capital investment in the project, it is doing more than setting up a local production facility run by its own cadre from the home office.

Intel is building on the investments made by the Costa Rican government in education over the past several decades (because there is no standing army, the funds that many of the neighboring countries spend on military concerns are instead invested in education and environmental protection in Costa Rica), so in a sense, there is a partnership. The government offers a well-educated populace (the literacy rate of Costa Rica is said to be higher than that of the United States), and Intel, acting in its own economic interest as well as that of the country, takes those people and trains them to compete in the new era of global technology-based economic competition.

Another example from Costa Rica is the Aerial Tram. This is the most visited private tourist attraction in Costa Rica (second only to the National Parks system in total visitors), designed to allow visitors to travel by cable car through the canopy of the rain forest. The infrastructure was built using sound ecological practices including the use of helicopters to drop in pylons for the cable system so as not to disturb the jungle floor or any trees. Although the capital for the creation and development of this company is predominantly foreign and the company is explicitly profit oriented, its vision is to serve as a model for environmental protection by showing alternative methods to profiting from the rain forest without cutting down its trees.

The management and staff of the Aerial Tram are nearly all locals who have been trained by the entrepreneurs who founded the venture. In this sense, the company has become a source of economic development for the local community as much as for its own interest. Beyond its normal business operations, which are essentially designed to provide an enjoyable educational experience, the 
company also engages in not-for-profit educational activities. Free of charge, it regularly hosts students from the public school system of the country, teaching them about the importance of protecting the rain forest. Rather than merely maximizing short-term revenues, this company has made social and economic investments for the long run.

\section{Joint Partnerships in Costa Rica (Cell III)}

The hotel industry in Costa Rica illustrates this Cell III type of development. Costa Rica began developing a global reputation as a tourist destination during the 1980s, particularly after the president won the Nobel Peace Prize. Prior to this period, the hotel industry was relatively small, but as demand grew, many Costa Ricans decided to enter the hotel business. Most of the new hotels were owned and managed by inexperienced investors who learned the business by trial and error. Some of the new hotels were operated by multinational chains that operated in Costa Rica using staff and management from their global operations. Eventually, some local investors asked foreign hotel operators to join them in entering the market as joint partners. The most notable of these was the case of the recently built Marriott Hotel.

The concept to build the Marriott Hotel in Costa Rica came from a group of local successful entrepreneurs (from outside the hotel industry) who wanted to diversify their holdings. Because of Marriott's world-class reputation as a hotel operator, these entrepreneurs asked the company to take a stake in their venture and offered the company a contract to manage the hotel. Although the Marriott company's stake is relatively small, it is large enough to show its commitment to the market. Moreover, the company is being asked to sell its industry expertise to a group of successful local businesspeople. Marriott's stake is largely symbolic, but the inside pull from local investors is significant.

In addition to managing the hotel, Marriott uses what might be the largest training and development budget of any hotel in the region to develop its staff. This model has worked so well in Costa Rica that this model has since been replicated in other countries in the region including Guatemala, El Salvador, and Panama-each with majority local shareholders, a minority stake by Marriott, and a strong training and development component. The hotel industry shows signs of a Cell III form of development precisely because local investors have taken the lead and have brought in multinational partners only for those management tasks that the entrepreneurs cannot effectively handle on their own.

\section{Integrated Social Covenants in Costa Rica (Cell IV)}

The world trend toward environmental conservation and ecological issues has helped to establish ecotourism as a substantial component of the tourism industry within Costa Rica. The biological diversity 
and political stability of Costa Rica succeeded in attracting entities such as the Organization for Tropical Studies (which gathers 55 universities of international renown), the Tropical Agronomic Center for Research and Education, and the Inter-American Institute of Cooperation for Agriculture. For many years, these institutions have done first-class research in the country and have spread the name of Costa Rica among academicians, environmental groups, and the global public interested in environmental preservation as a very special country by reason of its biodiversity and commitment to conserving the environment. Also, Costa Rica has created an exemplary national park system with relatively easy access and a large percentage of national territory (nearly one quarter). These factors contribute to the positioning of the country as a very attractive destination for those tourists who, for professional or personal reasons, are interested in environmental or naturalist issues.

Because the majority of Costa Rica's visitors engage in activities related to natural attractions, this raises the stakes of the partnership between the public and private sectors and between tourism interests and preservation interests. Mass tourism to the country through the usual multinational contractual relationships so prevalent in other developing countries, and clearly within a Cell I framework, creates a dilemma for the country. Which model or approach should Costa Rica employ? Can the country do both at the same time and not confuse global customers and partners alike? Answers to these questions depend on whether a Cell I approach (mass tourism) is consistent with the principles and image that Costa Rica has worked so hard to develop.

The economic benefits that ecotourism has created have led some local entrepreneurs to capitalize on the image that the pioneers (Cell II) created without necessarily adhering to the conservationist/environmentalist principles. Some tour operators and hotel owners misuse the term ecotourism to attract a growing population of travelers who are concerned with the environment. The incentive to operate from a Cell III position and "free ride" on the Cell II social contract is great given that most travelers are inclined to pay more for the "privilege" of experiencing a well-preserved natural environment. This has raised difficult questions. Some of the pioneers claim that these new free-riding entrepreneurs are diluting the value and integrity of the equity created by the pioneers. However, these recent entrepreneurs ultimately might help the pioneers to achieve their goals and move toward Cell IV.

Given a limited national budget for tourism promotion, the private sector promotions of Costa Rica (greatly increased by these newer free-riding tour wholesalers/operators, hotels, etc.) as a "natural" destination undoubtedly have led to greater visibility and increased visitation. These visitors spend money visiting protected areas, which in turn ensures their continued protection. 
To accomplish the sustainability of the eco-destination requires a new approach to partnership. A social covenant approach provides an option for balancing the environmental, social, and economic agendas. Accomplishing this cooperation might depend on getting more of Costa Rica's citizenry, including those with no direct financial stake in the industry, to understand both the importance of the industry to the country's economy and the relation between sustainable environmental practices and their own behavior. Careful planning and the development of innovative relationships that share the benefit of tourism development are worthy challenges for the leaders of this developing country.

The first step in facilitating any strategic partnership, and particularly building Cell IV forms of social covenants, is to recognize the varied elements of the economic activities that make up the tourism cluster in Costa Rica. Figure $\mathbf{7 . 4}$ shows a diagram of the main tourism cluster in Costa Rica, namely, that revolving around tourists particularly inclined to nature-related activities.

FIGURE 7.4. Tourism Cluster in Costa Rica

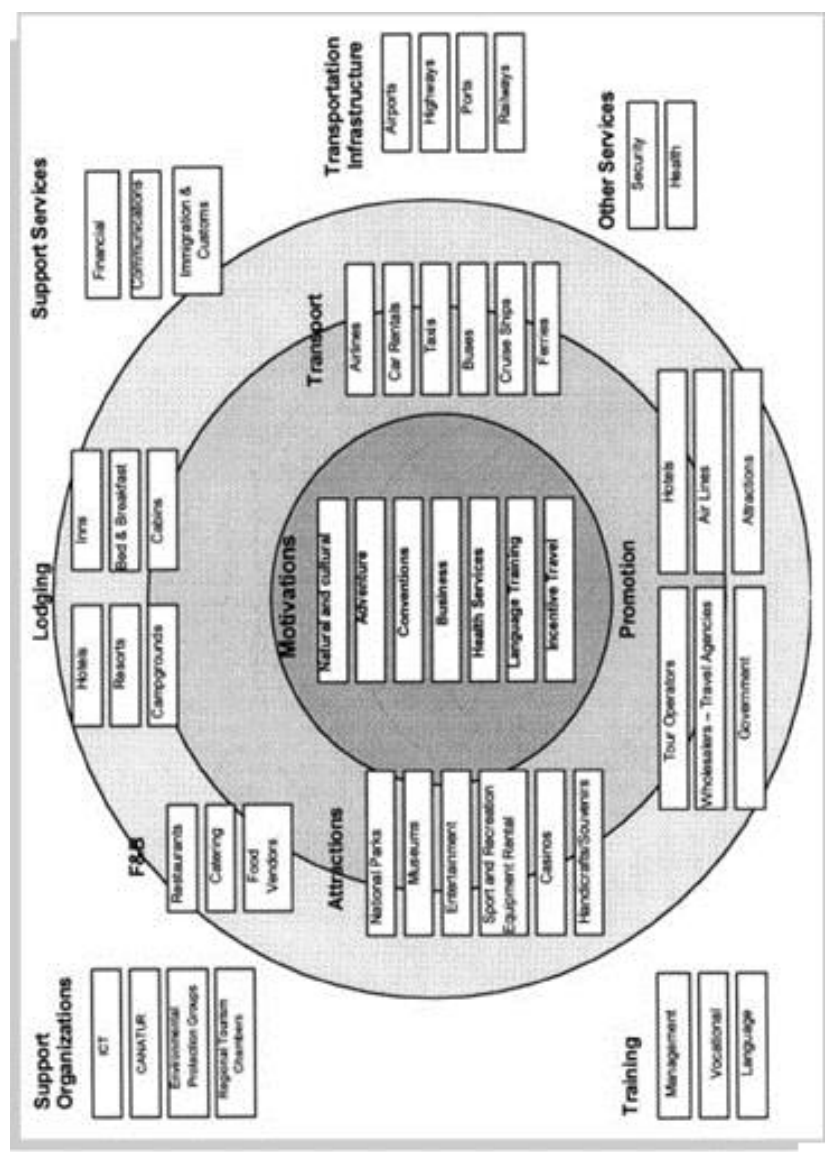

NOTE: $I C T=$ Instituto Costarricense de Turismo $($ Costa Rica Tourism Institute): CANATUR $=$ Camara Nacional de Turismo (National Tourism Chamber); F\&B $=$ Food and Beverage. 
At the cluster center are the motivations to visit the country, of which the most relevant are those having a direct relationship to nature. In a circle around motivations are industry sectors with a direct interface with tourists. These are the lodging, transportation, food and beverage, attractions, and promotion sectors. On the peripheral circle are support and related sectors. These are defined as sectors important to the service ultimately received by tourists, although not having a direct interaction with them but rather supporting and supplying the sectors directly related to visitors.

In a Cell I model of contractual relationships, various businesses in the cluster could work independently and for the interests of the one or two financial players involved in the contract. In a Cell II model, caretaker organizations might be established to preserve and protect the environment or might be established as socially conscientious businesses that preserve the forests while building eco-friendly operations. A Cell III model might be represented in the existence of more local lodging, attraction, training, promotion, food and beverage, transportation, and other service businesses and associations working for individual economic gains but in joint venture arrangements or strategic alliances that provide for bundling of services to the global ecotourist customer. A series of local hotels could contract with local car rental, bus, and taxi services to transport guests to national parks. In a Cell IV model, the various individual entities would work in collaboration with local community members to accomplish the objectives of greater economic benefits to the community members, creating more jobs, and building infrastructure and support services. In Costa Rica, this Cell IV approach would reduce demand for pastures because the citizens no longer would need the agricultural lands for survival, thus curbing deforestation.

We argue that the development and enhancement of the tourism clusters provide benefits to all businesses. By working together to protect the environment, companies share information and contribute to the success of other businesses. An example of this is clearly reflected in Barra Honda National Park, where visitors find services that usually are nonexistent in these zones-a typical food restaurant, lodging, camping facilities within a natural dry forest, a deer nursery, a handicraft shop, a parking area, and local guides. All of these services are the responsibility of a Pro-Development Association, made up of community members, and are offered on the park periphery to leave the natural reserve untouched. In addition, they are voluntarily involved in controlling fires within the park and reforesting with pochote (Bombacopsis quinatum) trees. Finally, they provide training in diverse topics such as food handling, English, fire control, and soil conversation.

\section{Implications for Future Research}

The framework for social partnerships and the importance of an integrated social covenant approach suggested in this chapter create various avenues for future researchers to examine at the macro, meso, 
and micro levels. At the macro level, research is needed to examine differences across industries (e.g., manufacturing, telecommunications, agriculture, tourism, financial services) in their design of cooperative partnerships and how these various industries progress toward a Cell IV form of relationship. Future studies could identify the structural barriers within different industries and different developing countries to the establishment of social contracts. Specifically, research examining the characteristics that allow industries and companies to be more agile in their responses to the demands of a rapidly changing environment and sensitive to the unique needs within each partnership would help to define effective paths toward building social contracts. Studies determining which elements in an economic development plan are critical to building social contracts and the minimum requirements necessary in developing countries with regard to infrastructure, political stability, democratization, socioeconomic composition, and the like clearly are needed. Do the dynamics of social contracts differ by region of the world such that Asian, European, African, and American approaches differ? Case studies examining other Central American countries would contribute to further understanding of the conditions needed for change in the region and the likelihood that these countries can move toward social contract forms of global relationships for long-term sustainable development. Even within the United States, the possibility of building social contracts between Native American Indian nations and the federal government might be a promising area for future study.

At the meso level, longitudinal research is needed examining a company's staging and execution of an integrated social covenant form of strategic social partnership. Detailed analyses of how a company goes about the internal changes needed to incorporate this different managerial philosophy and of the interactions with various entities in the developing country will contribute to the understanding of how to design and sustain these cooperative partnerships. The structure of the MNC also can play a role in determining its ability and success in forming new social partnerships. It is possible that agile, matrixed, or networked internal operating systems will enhance the ability of an MNC to form numerous social partnerships. Will the global networks of the federal design presented by Handy (1992) or other forms of innovative organizational design influence the ease and effectiveness of social partnership? Studies also could examine within-country experiments in which global organizations that are operating with Cell I, Cell II, and Cell III forms of partnership are willing to explore building a different model of partnership in an enclave in the country so that comparisons can be drawn among the different approaches. We see naturally occurring experiments extremely promising in the hospitality industry because so much development is under way in Central America that is done in isolated enclaves within countries. It would be interesting to see whether there are specific instances in which the models of Cell I, Cell II, and Cell III are more desirable and productive than the orientation suggested in Cell IV. 
At the micro level, research is warranted on the relationships between the four different forms of partnership and the job attitudes of local employees, expatriate managers, and host country managers. The influence of the different forms of partnership on customer loyalty, purchase decisions, and customer satisfaction also would be a fruitful line of inquiry. In addition, studies that examine the managerial skills necessary to operate successfully in an integrated social covenant form of relationship with local communities in developing countries are needed. The ability to speak the local language; knowledge of local culture, history, values, and skill levels of the residents; skill in negotiating, understanding of self-knowledge, understanding of differences, and understanding of appropriate managerial styles and techniques in different work environments (Earley \& Erez, 1997) can be crucial competencies for managers working in a social contract in developing countries. The role of training and models for building life and work skills for employees in rapidly evolving economies also would add value to our understanding of cooperative models. The integration and conflicts among personal, work, organizational, and country values would be an exciting stream of research that could be developed by examining employees employed for organizations using the various models described in this chapter.

\section{Conclusion}

The major premise of this chapter is that sustainable competitive advantage will come from a new way of thinking about partnerships and a different orientation toward relationships with competitors, investors, employees, and the local governments and citizens. It will become increasingly difficult to do business without collaborating and cooperating with the broader community. The future for Central America in particular is not banana republics but rather new industry-based clusters. Two drivers of this new era are the economic gains to be accrued from interdependence and the genuine good for the society. These two benefits support and enhance each other. Flexible human resource strategies and practices will fuel and sustain the shared economic gains. However, as our illustration of ecotourism in Costa Rica suggests, a movement toward the new social contract is fragile and vulnerable. Inertia and resistance to change are formidable barriers. Nevertheless, the more businesses and countries work to create these social partnerships, the more they will become viable and enduring.

\section{Note}

1. Referring to a country as a "banana republic" is a highly charged phrase, and we use it as such to illustrate the dramatic implications of a country that has managed to escape the confines of such a pejorative descriptor. 


\section{References}

Adler, N. J., Brahm, R., \& Graham, J. L. (1992). Strategy implementation: A comparison of face-to-face negotiations in the People's Republic of China and the United States. Strategic Management Journal, 13, 449-466. http://dx.doi.org/10.1002/smj.4250130605

Andrews, K. R. (1980). The concept of corporate strategy. Homewood, IL: Irwin.

Bowie, N. E. (1991). The firm as moral community. In R. M. Coughlin (Ed.), Morality, rationality, and efficiency: New perspectives on socio-economics (pp. 169-193). Armonk, NY: M. E. Sharpe.

Boynton, L. L. (1986). The effects of tourism on Amish quilting design. Annals of Tourism Research, 13, 451-465. http://dx.doi.org/10.1016/0160-7383\%2886\%2990030-7

Creed, W. E., \& Miles, R. E. (1996). Trust in organizations: A conceptual framework linking organizational forms, managerial philosophies, and the opportunity costs of controls. In R. Kramer, \& T. Tyler

(Eds.), Trust in organizations: Frontiers of theory and research. Thousand Oaks, CA:

Sage. http://dx.doi.org/10.4135/9781452243610

De Forest, M. E. (1994). Thinking of a plant in Mexico? Academy of Management Executive, 8, 33-40.

Donaldson, T. (1982). Corporations and morality. Englewood Cliffs, NJ: Prentice Hall.

Earley, P. C., \& Erez, M. (1997). The transplanted executive. New York: Oxford University Press.

Etzioni, A. (1988). Capital corruption: The new attack on American democracy. New Brunswick, NJ: Transaction Books.

Etzioni, E. (1993). The spirit of community. New York: Crown.

Friedman, M. (1962). Capitalism and freedom. Chicago: University of Chicago Press.

Greenwood, D. (1989). Culture by the pound: An anthropological perspective on tourism as cultural commoditization. In V. L. Smith (Ed.), Hosts and guests: The anthropology of tourism (pp. 171-185). Philadelphia: University of Pennsylvania Press. 
Hall, R. H. (1991). Organizations, structures, processes, and outcomes. Englewood Cliffs, NJ: Prentice Hall.

Handy, C. (1992). Balancing corporate power: A new Federalist paper. Harvard Business Review, 70(6), $59-72$.

Harrison, D. (1992). Tourism to less developed countries: The social consequences. In D. Harrison (Ed.), Tourism and the less developed countries (pp. 19-34). London: Belhaven.

Kanter, R. M. (1995). World class: Thriving locally in the global economy. New York: Touchstone.

Kochan, T. (1997, October). Beyond myopia: Human resources and the changing social contract. Paper presented at the conference, "Research and Theory in Strategic Human Resource Management: An Agenda for the 21st Century," Cornell University, School of Industrial and Labor Relations, Center for Advanced Human Resources Studies.

Kramer, R., \& Tyler, T. (1996). Trust in organizations: Frontiers of theory and research. Thousand Oaks, CA: Sage. http://dx.doi.org/10.4135/9781452243610

Latane, B., \& Darley, J. (1970). Unresponsive bystander: Why doesn't he help? New York: Appleton.

Lewellan, T. C. (1995). Dependency and development: An introduction to the Third World. Westport, CT: Bergin \& Garvey.

Mahoney, J. T., Huff, A. S., \& Huff, J. O. (1994). Toward a new social contract theory in organizational science. Journal of Management Inquiry, 3, 153-168. http://dx.doi.org/10.1177/105649269432005

Noronha, R. (1979). Paradise revisited: Tourism in Bali. In E. de Kadt (Ed.), Tourism: Passport to development? (pp. 177-204). Oxford, UK: Oxford University Press.

Oppermann, M., \& Chon, K-S. (1997). Tourism in developing countries. London: International Thomson Business Press.

Powell, W. (1996). Trust-based forms of governance. In R. Kramer, ed. \& T. Tyler (Eds.), Trust in organizations: Frontiers of theory and research. Thousand Oaks, CA: Sage. http://dx.doi.org/10.4135/9781452243610 
Reich, R. B. (1998). The new meaning of corporate social responsibility. California Management Review, 40(2), 8-17. http://dx.doi.org/10.2307/41165930

Rousseau, D. (1995). Psychological contracts in organizations: Understanding written and unwritten agreements. Thousand Oaks, CA: Sage. http://dx.doi.org/10.4135/9781452231594

Shane, S. (1994). The effect of national culture on the choice between licensing and direct foreign investment. Strategic Management Journal, 15, 387-394.

Sheahan, J. (1987). Patterns of development in Latin America. Princeton, NJ: Princeton University Press.

Shrivastava, P. (1995). The role of corporations in achieving ecological sustainability. Academy of Management Review, 20, 936-961.

Tolbert, P., \& Zucker, L. (1983). Institutional sources of change in the formal structure of organizations: The diffusion of civil service reform, 1880-1935. Administrative Science Quarterly, 28, 22-39.

Tushman, M. L., \& O'Reilly, C. A. (1997). Winning through innovation. Boston: Harvard Business School Press.

Williamson, O. (1975). Markets and hierarchies: Analysis and antitrust implications. New York: Free Press. 